\title{
Analisis Kemampuan Pemahaman Kognitif Dan Kesulitan Belajar Matematika Konsep "Logika” Dengan Model Pembelajaran Daring
}

\author{
Andri Anugrahana \\ andrianugrahana@gmail.com \\ Universitas Sanata Dharma \\ Analysis Of Cognitive Understanding Abilities And Difficulties In Learning Logic Mathematics \\ With The Line Learning Model
}

\begin{abstract}
This study aims to describe the results of the analysis of cognitive comprehension abilities and learning difficulties in mathematics logic subject using the online learning model for PGSD students at Sanata Dharma University. The research method used is descriptive research method. The research involved PGSD students of Sanata Dharma University in 2020/2021 with data collection techniques and information through a student response questionnaire instrument and cognitive ability test questions using Google form. The results of the study explain that the implementation of online learning regarding the concept of logic has used applications such as WhatsApp, LMS, zoom, google meet, google form. Analysis of students' cognitive abilities is measured by tests that have met the cognitive dimension standards according to Bloom's Taxonomy and the results of student completeness that reach above the KKM are $38 \%$, while the number of students below the KKM reaches $62 \%$. Student difficulties can be divided into two types, namely conceptual difficulties and technical difficulties in implementing online learning.
\end{abstract}

Keywords: Analysis, Cognitive Comprehension Ability, Learning Difficulties, Mathematics

\section{Article Info}

Received date: 10 Desember 2020 Revised date: 14 Januari $2021 \quad$ Accepted date: 19 Januari 2021

\section{PENDAHULUAN}

Proses Pembelajaran merupakan proses yang membutuhkan interaksi dari pembelajar dan pemelajar. Proses ini dapat dilakukan dari interaksi antara dosen dan juga mahasiswa. Hal ini juga disampaikan oleh Putria, H., Maula, L. H., \& Uswatun, D. A. (2020). Yang menjelaskan bahwa dalam proses pembelajaran melibatkan kegiatan kegiatan belajar dan mengajar yang dapat menentukan keberhasilan serta untuk mencapai tujuan pembelajaran. Perguruan tinggi sebagai lembaga pendidikan tinggi dalam proses belajar mengajarnya dikenal dengan istilah perkuliahan. Dalam proses perkuliahan, dosen berperan menyampaikan dan menjelaskan materi, agar dapat dipahami dan dikuasai oleh mahasiswa. Untuk mencapai tujuan pembelajaran yang diharapkan maka dibutuhkan rancangan dan bahan materi yang dapat menunjang proses pembelajaran. Rancangan yang disiapkan dengan baik akan dapat membantu dosen dalam memfasilitasi mahasiswa dalam perkuliahan. Pelaksanaan pembelajaran biasanya dilakukan dengan luring (luar jaringan) yaitu dengan tatap muka antara dosen dan mahasiswa. Tetapi pada masa pandemi Covid-19 ini Pemerintah mengeluarkan kebijakan pembelajaran daring (dalam jaringan). Santika, I. W. E. (2020) mengartikan dalam jaringan sebagai terhubung melalui jejaring komputer, internet, dan sebagainya. Pembelajaran during dilaksanakan sebagai langkah tepat untuk dapat mencegah dan menekan penularan virus Covid-19, peserta didik tidak akan ketinggalan pelajaran sebagaimana yang telah direncanakan dalam kurikulum selama satu tahun ajaran. Meskipun pemerintah sudah mengeluarkan kebijakan New Normal, tetapi untuk pendidikan khususnya pembelajaran di sekolah ataupun di kampus belum sepenuhnya dibuka oleh pemerintah. Hal ini dikarenakan kecenderungan mahasiswa untuk berkumpul sehingga memungkinkan terjadinya penyebaran virus tersebut. Karena alasan inilah maka pelaksanaan pembelajaran masih bersifat during termasuk pembelajaran matematika. Maulana (2017) menjelaskan matematika adalah aktivitas (human activity) dan oleh karenanya matematika dapat kita pelajari dengan baik bila disertai dengan mengerjakan (doing mathematics). Aktivitas dalam pembelajaran matematika secara daring menjadi 
tantangan bagi dosen dan juga pendidik lainnya. Pembelajaran matematika yang biasanya disampaikan secara langsung dan dapat dijelaskan secara langsung pada mahasiswa, saat ini menjadi pembelajaran yang dilakukan secara daring.

Kumalasari, A., \& Sugiman, S. (2015) menekankan bahwa Proses belajar yang terjadi pada mahasiswa merupakan sesuatu yang penting, karena melalui belajar mahasiswa mengenal lingkungannya dan menyesuaikan diri dengan lingkungan di sekitarnya. Suatu pengetahuan, sikap, dan keterampilan pada dasarnya dapat dipindahkan melalui proses belajar dengan berbagai cara. Oleh karena itu, pentingnya rancangan yang mampu mengembangkan pengetahuan, sikap dan juga keterampilan. Rancangan pembelajaran yang tepat pada kondisi pandemik Covid 19 saat ini adalah pembelajaran matematika secara daring. Dosen ataupun pendidik khususnya matematika memiliki tantangan yang besar dalam melakukan pembelajaran dengan sistem daring. Dosen harus mampu merancang mekanisme komunikasi dengan mahasiswa dann menyusun rencana pembelajaran yang berkelanjutan dan bermakna sesuai kondisi mahasiswa saat ini. Artinya dosen diharapkan mampu menciptakan pembelajaran matematika secara daring yang menyenangkan dan mampu mengakomodir tujuan pembelajaran yang akan dicapai. Proses belajar yang terjadi pada mahasiswa merupakan sesuatu yang penting karena disini terjadi proses transfer pengetahuan dari pembelajar dan pemelajar. Transfer pengetahuan yang tidak sempurna menyebabkan mahasiswa itu tidak dapat memahami pelajaran yang berlangsung dan juga kesalahan konsep yang akan diterapkan. Keadaan ini dijelaskan oleh Kumalasari, A., \& Sugiman, S. (2015) bahwa mahasiswa tidak dapat belajar sebagaimana mestinya hal itu yang disebut dengan kesulitan belajar mahasiswa. Yusmin, E. (2017). Menambahkan bahwa pembelajaran matematika, pengalaman dan konsepsi (kerangka berpikir) siswa perlu dilibatkan, kadang-kadang konsepsi yang dimiliki siswa tidak akurat karena terjadi miskonsepsi. Apabila guru yang mengajar tidak memperhatikan konsepsi awal siswa, guru tidak akan berhasil menanamkan konsep baru dengan benar. Kasus-kasus seperti inilah yang akan memunculkan kesulitan dalam belajar.

Pada program pendidikan guru sekolah dasar, mata kuliah matematika juga dijadikan mata kuliah wajib. Mata kuliah ini diberikan kepada mahasiswa semester 1 dengan harapan dapat membekali mahasiswa dalam hal kemampuan khususnya logika. Berbagai konsep mengenai matematika tersebut diberikan pada mahasiswa menggunakan berbagai metode pembelajaran seperti pendekatan berbasis kontekstual, metode tanya jawab, diskusi, dan pemberian tugas. Diharapkan para mahasiswa dapat mengkaitkan berbagai konsep matematika tersebut dengan fenomena yang terjadi pada kehidupan sehari-hari. Dengan bekal kemampuan ini, diharapkan mahasiswa dapat menyelesaikan masalahmasalah faktual terutama dalam hal pembuktian suatu dalil atau teorema sehingga akan sangat menunjang kegiatan pembelajaran ketika mahasiswa tersebut menjadi pengajar (guru). Dalam mengikuti mata kuliah matematika khususnya konsep logika mahasiswa dituntut untuk selalu memiliki kesiapan belajar yang baik disamping tentunya membutuhkan daya nalar. Oleh karena itu, sebagian besar mahasiswa menganggap bahwa logika matematika merupakan mata kuliah yang sulit. Hal ini berdampak kepada belum optimalnya capaian belajar mahasiswa, masih ditemukan mahasiswa yang belum memahami konsep sehingga beberapa mahasiswa memilih untuk mengulang kembali mata kuliah ini. peneliti memandang pemahaman konsep mahasiswa dapat ditingkatkan melalui pembelajaran matematika. Kusuma, J. W., \& Caesarani, S. (2019). memandang pemahaman konsep dapat ditingkatkan melalui pembelajaran yang memberikan konflik dalam skema berpikirnya Dengan memberikan konflik dalam pikiran mahasiswa, maka diharapkan mahasiswa akan lebih paham dan mengerti atas apa yang telah dipelajari sebelumnya lalu dikaitkan dengan materi pelajaran yang diperoleh saat pembelajaran. Hal ini juga ditegaskan dalam Permendikbud nomor 3 tahun 2020 tentang Standar Pendidikan Nasional Tinggi pasal 9 dijelaskan bahwa lulusan program diploma empat dan sarjana paling sedikit menguasai konsep teoritis bidang pengetahuan. Ini membuktikan bahwa mahasiswa perlu mendapatkan bekal yang kuat khususnya dalam kemampuan kognitif. Selain itu Darmawan, I. P. A., \& Sujoko, E. (2013) menambahkan bahwa belajar yang bermakna menghadirkan pengetahuan dan proses kognitif yang siswa butuhkan untuk menyelesaikan masalah. Oleh karena itu, perlu standar untuk mengukur kemampuan koqnitif mahasiswa yaitu dengan menggunakan dimensi pengetahuan Taksonomi Bloom ranah kognitif yang telah direvisi Anderson dan Krathwohl (dalam Gunawan, I., \& Palupi, A. R.) .yakni: mengingat (remember), memahami/mengerti (understand), menerapkan (apply), menganalisis (analyze), mengevaluasi (evaluate), dan menciptakan (create). Wulan, A. R. (2008) menambahkan bahwa C1 (Mengingat), C2 (Memahami), C3 (Mengaplikasikan), C4 (Menganalisis), C5 (Mengevaluasi), C6 (Mencipta). Iskandar, D., \& Senam, S. (2015) menjelaskan 
bahwa pengetahuan unsur C1, C2, C3 merupakan kategori lower order thinking skills (LOTS) atau keterampilan berfikir tingkat rendah sedangkan C4, C5, C6 termasuk dalam higher order thinking skills (HOTS) atau keterampilan berpikir tingkat tinggi. Tidak hanya itu saja, kondisi saat ini masa pandemi Covid-19 dosen harus kreatif dan mampu mendesains pembelajaran yang baik. Hal ini didukung juga pendapat Mawardi (2020) bahwa pada masa pandemi Covid -19 para dosen ditantang untuk merancang pembelajaran daring secara inovatif. Kualitas rancangan pembelajaran daring itu sendiri ditentukan oleh kemampuan dosen dalam mempersiapkan komponen komponen pembelajaran dan mengintegrasikannya dengan baik. Oleh karena itu peneliti merancang penbelajaran daring dengan maksimal. Hal ini dilakukan dosen dengan memanfaatkan Learning Management System(LMS)untuk mendesain pembelajaran daring. Tidak hanya itu saja dosen juga menggunakan tambahan platform medsos seperti What App, Google Meet, Zoom dan Google Classroom. Rancangan pembelajaran model daring diharapkan dapat mendukung kompetensi dalam pembelajaran matematika. Setyowati, N., \& Mawardi, M. (2018) menjelaskan kompetensi yang ingin dicapai dan ruang lingkup muatan pelajaran matematika diharapkan peserta didik mampu berpikir logis, analitis, sistematis, kritis, dan kreatif serta mampu bekerjasama.

Tujuan penelitian ini adalah memberikan gambaran pelaksanaan perkuliahan matematika "konep logika" secara daring. kedua, mendeskripsikan pemahaman konsep mahasiswa dalam memahai konsep logika, dan juga menyelesaikan permasalahan berkaitan dengan logika. Pembelajaran dilaksanakan secara daring karena pada dasarnya mengacu pada prinsip pelaksanaan Belajar Dari Rumah (BDR) sesuai dengan Serat Edaran (SE) Mendikbud No. 4 tahun 2020 diantaranya kegiatan BDR dilaksanakan untuk memberikan pengalaman belajar yang bermakna bagi peserta didik, tanpa terbebani tuntutan menuntaskan seluruh capaian kurikulum. "Materi pembelajaran bersifat inklusif sesuai dengan usia dan jenjang pendidikan, konteks budaya, karakter dan jenis kekhususan peserta didik. Aktivitas dan penugasan belajar dari rumah dapat bervariasi antar daerah, satuan pendidikan dan peserta didik sesuai minat dan kondisi masing-masing, termasuk mempertimbangkan kesenjangan akses terhadap fasilitas BDR (Belajar Dari Rumah). "Hasil belajar peserta didik selama BDR diberi umpan balik yang bersifat kualitatif dan berguna dari guru tanpa diharuskan memberi skor/nilai kuantitatif. Model pembelajaran dalam jaringan menekankan pada pola interaksi dan komunikasi yang positif dalam hal ini dosen dan mahasiswa.

\section{KAJIAN PUSTAKA}

\section{Kemampuan Pemahaman Kognitif}

Nuraeni, D., Uswatun, D. A., \& Nurasiah, I. (2020) menjelasakan bahwa pemahaman merupakan suatu kemampuan untuk memahami atau mengerti suatu hal yang dimaksud. Sedangkan Kognitif merupakan keterampilan yang berbasis otak dan digunakan untuk menyelesaikan tugas apapun secara bertahap. Sehingga pemahaman kognitif adalah pemahaman untuk memahami sesuatu yang berbasis otak secara bertahap.

\section{Kesulitan Belajar Matematika}

Keberhasilan mahasiswa yang kurang maksimal dalam perkuliahan di kelas dapat dimungkinkan karena terdapat kesulitan belajar dalam diri mahasiswa. Mahasiswa ataupun siswa yang mengalami kesulitan belajar cenderung mengalami kesulitan dalam memecahkan masalah baik di dalam kelas maupun masalah dalam kehidupannya. Dijelaskan lebih lanjut oleh Tias, A. A. W., \& Wutsqa, D. U. (2015). Analisis kesulitan siswa SMA dalam pemecahan masalah matematika kelas XII IPA di Kota Yogyakarta. Jurnal Riset Pendidikan Matematika, 2(1), 28-39.Hal ini disampaikan oleh Terkait dengan proses pembelajaran, hal tersebut dimungkinkan terdapat faktor-faktor baik dari segi kognitif, emosi, maupun lingkungan sosial siswa yang menjadi pemicu kesulitan dalam proses belajar dan pemecahan masalah. Rahajeng, S. P. (2012). Kesulitan Belajar Matematika menegaskan bahwa Kesulitan belajar tidak selalu disebabkan oleh faktor intelegensi yang rendah, akan tetapi juga disebabkan oleh faktor-faktor selain intelegensi. Hal tersebut berarti bahwa IQ tinggi belum tentu menjamin keberhasilan belajar. Sulit belajar matematika tidak berarti anak tersebut tidak mampu belajar, tetapi mengalami kesulitan tertentu yang menjadikannya tidak siap belajar. Kesulitan belajar matematika pada umumnya berkaitan dengan ketidakmampuan anak dalam membaca, imajinasi, mengintegrasikan pengetahuan dan pengalaman, terutama dalam memahami soal-soal cerita 


\section{METODE PENELITIAN}

Jenis Penelitian Penelitian ini adalah penelitian deskritif. Tempat pelaksanaan Penelitian dilaksanakan di prodi Pendidikan Guru Sekolah Dasar Universitas Sanata Dharma Yogyakarta. Adapun waktu pengumpulan data pada Agustus - Oktober 2020. Subjek Penelitian Subjek penelitian ini adalah mahasiswa pendidikan guru Sekolah Dasar di Universitas Sanata Dharma yang sedang menempuh mata kuliah Pengantar Matematika dan mengalami kesulitan dalam konsep "logika". Jumlah mahasiswa yang terlibat dalam perkuliahan ini ada 244 mahasiswa. Prosedur Penelitian ini dilakukan pertama-tama mengumpulkan data melalui kemampuan kognitif dari mahasiswa dalam memahami konsep logika. Data diperoleh dari hasil tes dan angket dalam google form. KeduavSelanjutnya, mencari kesulitan mahasiswa dalam mengikuti kuliah pengantar matematika khusus konsep "logika" . Mahasiwa yang mengalami kesulitan adalah yang memperoleh skor di bawah 60. Adapun instrumen yang digunakan untuk menganalisis letak dan jenis kesulitan adalah tes logika. Data dikumpulkan melalui google form dan hasil tes. Hasil tes Instrumen yang digunakan untuk mengkonfirmasi kesulitan belajar matematika mahasiswa adalah soal tes kemampuan kognitif dengan menggunakan Google form.

\section{HASIL PENELITIAN DAN PEMBAHASAN}

\section{Gambaran Proses Pembelajaran Daring}

Pelaksanaan perkuliahan masa pandemic Covid-19 dengan menggunakan pembelajaran daring. Dimana proses pembelajaran daring yang digunakan adalah dengan menggunakan LMS usd.ac.id, WAG (whatsapp Group), Zoom meeting, google meet, dan google form. Pelaksanaan virtual meeting dengan menggunakan aplikasi zoom. Selanjutnya diskusi banyak juga dilakukan dalam forum diskusi. Bahan ajar yang digunakan dosen adalah dengan mengguakan video-video pembelajaran pada youtube. Tidak itu saja sistem kehadiran selain menggunakan presensi yang ada di lms, peneliti juga meminta ada presensi di zoom meeting. Pembelajaran jarak jauh atau daring ini dimulai pada perkuliahan awal, dimana mahasiswa belajar dari rumah. Untuk itu pentingnya pemahaman dosen berkaitan dengan pengguasaan teknologi bagi seorang dosen agar pembelajaran jarak jauh dapat berjalan dengan lancar. Dosen harus melakukan inovasi dalam pembelajaran diantaranya dengan memanfaatkan teknologi dalam pembelajaran. Teknologi yang digunakan lewat media online seperti Whatsapp, LMS, google meet, google form, zoom.. Metode perkuliahan yang digunakan adalah dengan menggunakan diskusi dan juga Tanya jawab. Diskusi dilakukan di forum diskusi LMS dengan mahasiswa dibagi dalam beberapa kelompok selanjutnya melakukan diskusi kelompok dalam LMS. LMS adalah Learning management System yang mana harapannya dapat membantu mahasiswa secara mandiri dalam memahami konsep logika. Hal ini juga didukung oleh Hidayat, H., Hartono, H., \& Sukiman, S. (2017). Pengembangan Learning Management System (LMS) dapat membantu mahasiswa belajar secara mandiri tanpa harus tergantung kepada seorang pengajar, dengan Learning Management System (LMS) sebagai media dimana nantinya seorang mahasiswa akan secara mandiri dapat melakukan pembelajaran (self learning).

Pelaksanaan pembelajaran yang diupayakan oleh dosen adalah dengan menggunakan Whatsapp Group, aplikasi ini digunakan dosen untuk berkoordinasi di awal dengan mahasiswa. Tidak hanya itu saja Whatshapp group juga digunakan sepanjang semester untuk koordinasi perkuliahan. Bahkan jika LMS tidak dapat bekerja dengan baik maka wa group menjadi salah satu solusi yang terbaik. Sejauh ini semua mahasiswa memiliki HP dan dapat mengoperasikan wa group. Selain itu, Universitas Sanata Dharma juga memfasilitasi dan memaksimalkan penggunaan aplikasi software yang dapat yang dapat membantu merencanakan, mengimplementasikan sebuah proses pembelajaran yaitu Learning Management System (LMS) belajar.usd.ac.id. Dosen melakukan eksplorasi secara mandiri dengan penggunaan LMS belajar.usd.ac.id dan beberapa aplikasi teknologi yaitu zoom meeting dan juga google meet, google form pada mata kuliah matematika konsep logika. Dosen menyiapkan bahan perkuliahan dan menguploud bahan seperti modul, video, soal latihan di LMS. Penggunaan LMS belajar.usd.ac.id tidak hanya untuk bahan ajar tetapi juga dilakukan untuk presensi kehadiran mahasiswa, pembentukan kelompok forum diskusi, dan juga uploud tugas. 

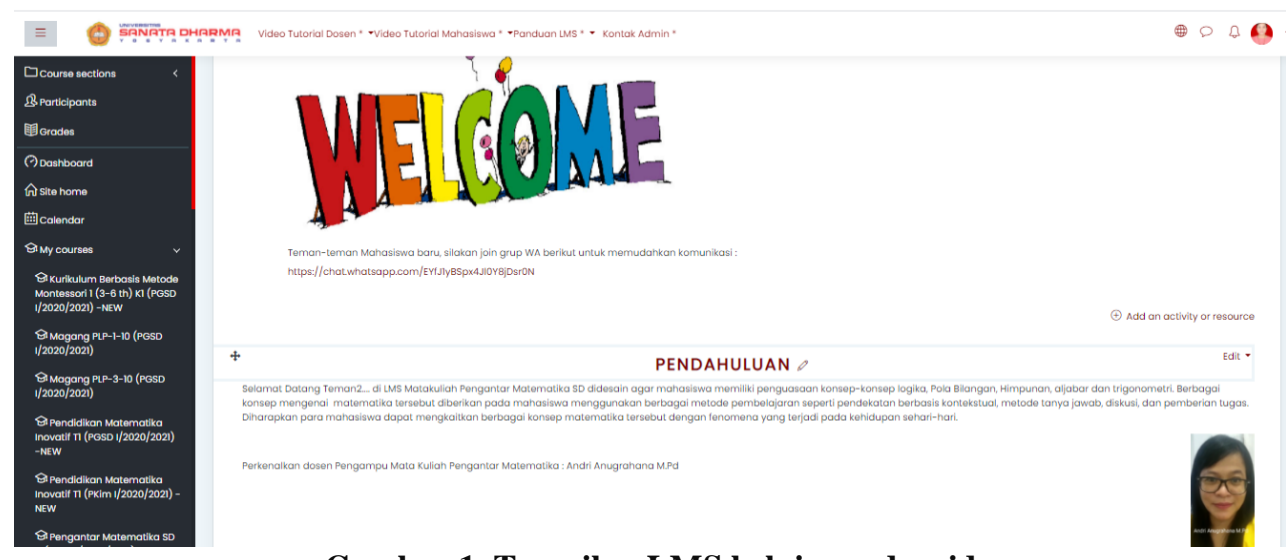

Gambar 1. Tampilan LMS belajar.usd.ac.id

Dosen melakukan aktivitas disetiap pertemuan dengan membuat presensi kehadiran di LMS, selanjutnya dosen menguploud bahan dan juga video pembelajaran konsep logika. Setelah melakukan presensi kehadiran mahasiswa diharapkan membaca terlebih dahulu konsep yang ada lalu mengirimkan di lms kesulitan yang dialami. Selanjutnya kegiatan dapat dilakukan dengan mahasiswa terlibat dalam forum diskusi dengan menyumbangkan saran ataupun ide sesuai dengan topik yang sedang dibicarakan. Kegiatan yang lain setelah presensi kehadiran adalah melakukan virtual meeting dengan aplikasi zoom. Tujuan virtual meeting adalah untuk klarifikasi, pembahasan dan pemantapan materi yang belum dipahami oleh mahasiswa mengkonfirmasi apa yang sudah dilakukan, melakukan pembahasan soal atau materi yang belum dipahami. Selain itu juga untuk memberikan penguatan dan peneguhan khususnya pada konsep logika. Pelaksanaan pembelajaran daring yang sudah dilakukan oleh dosen mendapat apresiasi dari mahasiswa sebesar 65\% dimana mahasiswa menyatakan senang mengikuti perkuliahan matematika konsep logika. Alasan lebih lanjut peneliti tanyakan pada virtual meeting kelas, dijelaskan bahea senang karena bisa mengikuti perkuliahan. Sedangkan sisanya 35\% menyatakan tidak senang karena mengalami kesulitan dalam memahami konsep logika.

\section{Analisis Pemahaman Konsep}

Analisis pertama, dilihat dalam pembelajaran matematika diukur dari hasil tes kemampuan mahasiswa dalam memahami konsep logika matematika. Hasil pemahan konsep mahasiswa dilihat dari hasil tes yang dilakukan oleh peneliti. Jumlah mahasiswa yang terlibat dalam penelitian ini 244 . Analisis soal lebih lanjut dijelaskan bahwa mahasiswa mengalami kesalahan pada saat soal-soal yang berkaitan dengan pernyataan majemuk. Kesalahan pada soal-soal yang berkaitan dengan soal yang mengajak mahasiswa berfikir lebih lanjut. Konsep logika yang dipahami oleh mahasiswa prodi Pendidikan Guru Sekolah Dasar tidak sama dengan logika pada prodi matematika. Berikut adalah rincian konsep logika, yaitu: pernyataan, operasi uner, Operasi biner,tautology, kontrdiksi, kontingensi, konvers, invers, kontraposisi dan penarikan kesimpulan. Penyusunan soal untuk evaluasi konsep logika, penulis menyusun dalam dua bagian yaitu didasarkan pada dimensi koqnitif. Dimana dimensi kognitif yang terbagi atas dua bagian yaitu LOTS dan HOTS. LOTS adalah low order thinking skill, dimana kemampuan berpikir ini masih mengandalkan ingatan otak bukan kemampuan otak untuk berpikir secara kritis. Tingkatan dalam taksonomi bloom meliputi mengetahui, memahami dan mengaplikasikan. Sedangkan untuk HOTS adalah kemampuan untuk mengajak mahasiswa berfikir tingkat tinggi. Soal tes yang disusun oleh dosen sudah memperhatikan dimensi LOTS dan HOTS.

Tidak hanya itu saja dosen juga sudah mengikuti revisi Taksonomi melakukan pemisahan yang tegas antara dimensi pengetahuan dengan dimensi proses kognitif. Fatmawati, S. (2013). Perumusan Tujuan Pembelajaran Dan Soal Kognitif Berorientasi Pada Revisi Taksonomi Bloom Dalam Pembelajaran Fisika. Dimensi pengetahuan dibedakan dalam empat jenis/dimensi pengetahuan yaitu Faktual, Konseptual, Prosedural dan Metakognif, sedangkan dimensi proses kognitif terdiri dari 6 (enam) proses yaitu Mengingat (C1), Memahami (C2), Mengaplikasikan (C3), Menganalisis (C4), Mengevaluasi (C5) dan Mencipta (C6)

Berikut Contoh soal yang digunakan sebagai soal untuk mengukur kemampuan koqnitif $\mathrm{C} 1$, $\mathrm{C} 2$ dan $\mathrm{C} 3$ adalah sebagai berikut. 
Tabel 1. Dimensi Kognitif LOTS

\begin{tabular}{|c|c|c|}
\hline Tingkat Kognitif Lots & Contoh soal & Keterangan \\
\hline $\begin{array}{l}\text { Mengingat } \\
\text { (C1) }\end{array}$ & $\begin{array}{l}\text { 3. Tika implikasi } p \rightarrow \sim q \text { bernilai S, maka implikasi berikut ini yang bernilai B adalah... } \\
\text { A. } \sim p \rightarrow q \\
\text { B. } q \rightarrow \sim p \\
\text { C. } p \rightarrow \sim p \\
\text { D. } q \rightarrow \sim q\end{array}$ & $\begin{array}{l}\text { Mengingat kembali } \\
\text { pemahaman dari } \\
\text { konsep implikasi } \\
\text { dalam soal }\end{array}$ \\
\hline $\begin{array}{l}\text { Memahami } \\
\text { (C2) }\end{array}$ & 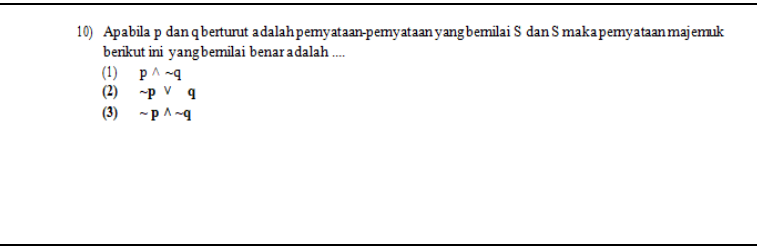 & $\begin{array}{l}\text { Membangun sebuah } \\
\text { pemahaman tentang } \\
\text { teori penarikan } \\
\text { kesimpulan dalam soal } \\
\text { yang berupa simbol } \\
\text { logika }\end{array}$ \\
\hline $\begin{array}{l}\text { Mengaplikasikan } \\
\text { (C3) }\end{array}$ & $\begin{array}{l}\text { 6. Kontraposisi dan implikasi: “Jika kuadrat suatu bilangan asli addalah genap, maka bilangan asli itu } \\
\text { adalah genap”, ddalah... } \\
\text { A. Jika bilangan asli itu tidak genap, maka kuadrat bilangan asli itu tidak genap } \\
\text { B. Jika bilangan asli itu genap, maka kuadrat bilangan asli itu genap } \\
\text { C. Jika kuadrat bilangan aslitidak genap, maka bilangan asti itu tidak genap } \\
\text { D. Jika kuadrat bilangan asli itu ganilil, maka bilangan asli itu ganill }\end{array}$ & $\begin{array}{l}\text { Menggunakan pola } \\
\text { implikasi untuk } \\
\text { diterapkan pada } \\
\text { pernyataan majemuk }\end{array}$ \\
\hline
\end{tabular}

Pada tabel 1. Diperoleh informasi bahwa model soal C1, C2, C3 adalah model soal dengan kriteria LOTS. LOTS adalah Mengingat, memahami, dan mengaplikasi. Pada soal bagian C1 dimana mahasiswa diberikan konsep yang hanya butuh ingatan saja untuk menjawab soal tersebut. Misalnya pada tabel 1. Soal no 3 mengajak mahasiswa hanya membuuhkan daya ingat untuk mengingat tabel kebenaran dari implikasi. Untuk soal no 10 mahasiswa diajak untuk memahami lebih lanjut berkaitan dengan semua konsep dan rumus dalam logika. Untuk bisa menjawab soal no 10, jika mahasiswa tidak memahami konsep lebih maka mahasiswa tidak akan bisa menjawab soal no 10. Jika tidak memahami lebih maka tidak akan dapat mengerjakan soal no 10. Hal ini dikarenakan soal saling berhubungan satu dengan yang lainnya. Untuk soal no 6 mengajak mahasiswa untuk mencoba mengaplikasikan apa yang mereka pahami tentang implikasi, selanjutnya mencoba diterapkan dalam soal bentuk pernyataan. Sebagian besar mahasiswa mampu untuk menyelesaikan. Hal ini juga didukung oleh tabel Nilai pemahaman kognitif matematika konsep logika. Sedangkan untuk dimensi kognitif HOTS dapat dilihat dari tabel 2 berikut ini.

Tabel 2. Dimensi kognitif HOTS

\begin{tabular}{|c|c|c|}
\hline Tingkat Kognitif Hots & Contoh soal & Keterangan \\
\hline $\begin{array}{l}\text { Menganalisis } \\
\text { (C4) }\end{array}$ & $\begin{array}{l}\text { 2. Pernyataan berikut ini yang merupakan modus ponens adalah } \ldots \\
\text { A. }[(a \rightarrow b) \wedge a] \rightarrow b \\
\text { B. }[(a \rightarrow b) \wedge \sim a] \rightarrow b \\
\text { C. }[(\sim a \rightarrow b) \wedge \sim a] \rightarrow b \\
\text { D. }[(a \rightarrow b) \wedge \sim a] \rightarrow \sim b\end{array}$ & $\begin{array}{l}\text { Mempraktekan salah satu contoh } \\
\text { dari tautologi di dalam soal }\end{array}$ \\
\hline $\begin{array}{l}\text { Mengevaluasi } \\
\text { (C5) }\end{array}$ & $\begin{array}{l}\text { 7. Jika diketahui premis-premis } a \rightarrow b, \sim a \rightarrow d \text { dan } \sim b \text {, maka kesimpulanya adalah } \ldots \\
\text { A. } a \\
\text { B. } b \\
\text { C. } a \\
\text { D. } \sim a\end{array}$ & $\begin{array}{l}\text { Memecahkan masalah penarikan } \\
\text { kesimpulan dengan } \\
\text { memepertimbangkan rasionalitas }\end{array}$ \\
\hline $\begin{array}{l}\text { Mencipta } \\
\text { (C6) }\end{array}$ & 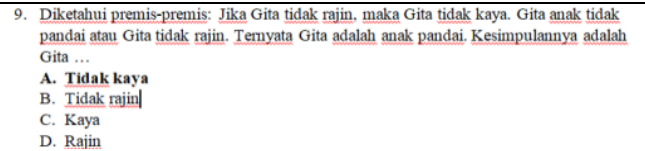 & $\begin{array}{l}\text { Mencari hubungan dari setiap } \\
\text { pertanyaan dan merumuskan } \\
\text { kesimpulan yang baru }\end{array}$ \\
\hline
\end{tabular}

Tabel 2 dimensi HOTS merupakan contoh soal yang diberikan ke mahasiswa untuk sampai pada tahap C4 yaitu menganalisis soal dan pada akhirnya C5 yaitu mengevaluasi dengan menentukan atau menarik kesimpulan yang diperoleh. Bahkan bisa sampai C6 mengkreasi karena mahasiswa sudah mampu membuat kesimpulan baru. Soal yang diberikan pada tabel 2 pada contoh 2 menjadi contoh dari C4 karena merupakan proses dengan tingkat kognitif lots dimana Pada soal tersebut mahasiswa diajak untuk berfikir lebih tinggi dan menarik sebuah kesimpulan dari dua premis. Mahasiswa dapat memahami lebih dalam bahwa untuk soal no 9, soal tersebut memiliki dua penarikan kesimpulan yaitu modus tollendo ponen dengan modus ponen.

Soal yang disusun oeh dosen sudah memenuhi kriteria soal dnegan menggunakan taksonomi bloom, dimana tingkatan soal yang dibuat dosen sudah memenuhi C6 dimana sampai pada mencipta dengan mencari hubungan dari satu konseo dengan konsep yang lainnya. 
Selanjutnta adalah menlihat lebih jauh terkait dengan hasil KKM mahasiswa saatm memahami konsep logika.

Analisis selanjutnya adalah analisis dengan melihat dari hasil KKM mahasiswa.

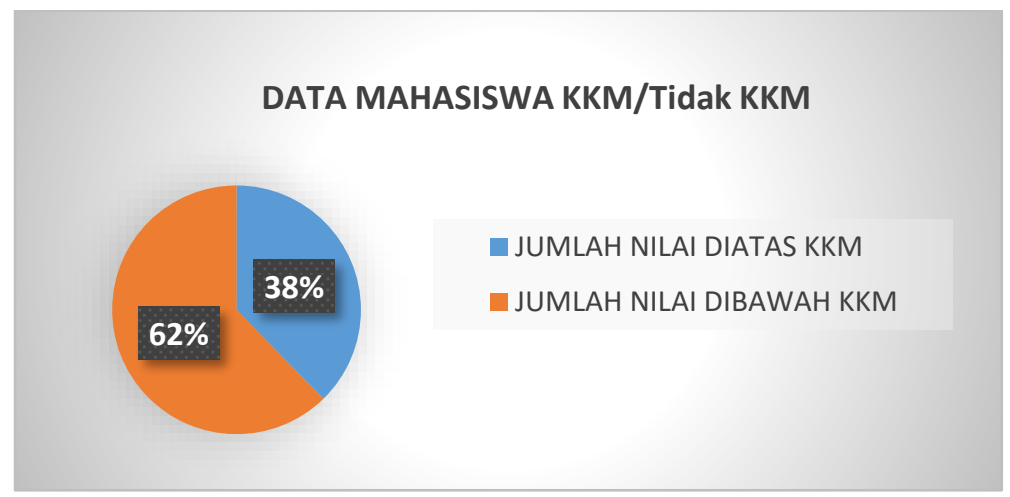

Gambar 2. diagram data siswa KKM

Apabila dilihat dari gambar 2 maka kita dapat melihat bahwa nilai ketuntasan pada mata kuliah matematika konsep logika adalah 70. Oleh karena itu, jumlah mahasiswa di atas KKM hanya mencapai $38 \%$, sedangkan jumlah mahasiswa dibawah KKM mencapai $62 \%$. Hal ini menunjukkan bahwa mahasiswa mengalami kesulitan dalam memahami konsep logika matematika. Hasillebih lanjut adalah aangket mahasiswa menunjukkan bahwa mahasiswa masih memiliki kesulitan memahami konsep logika. Berikut adalah urutan konsep logika yang menjadi permasalahan: pertama, Penarikan kesimpulan menjadi permasalahan pertama dalam memahami konsep dimana penarikan kesimpulan menjadi permasalahan di mahasiswa. Saat peneliti menanyakan secara langsung dalam virtual meeting, beberapa mahasiswa menyampaikan bahwa konsep ini menjadi masalah karena mahasiswa sulit membedakan antara modus ponen, modus tollen, modus tolendo ponen dan juga silogisme. Hal ini ternyata juga sejalan dengan hasil tes mahasiswa untuk konsep "logika". Hasil tes menunjukkan bahwa kesalahan mahasiswa juga memiliki kecenderungan pada konsep yang berkaitan dengan penarikan kesimpulan.

Analisis yang lain juga mendukung adalah nilai pemahaman konsep logika. Nilai pemehaman konsep logika dapat dilihat dari nilai yang tertinggi, nilai yang terendah, rata-rata, nilai diatas KKM dan nilai dibawah KKM.

Tabel 3. Nilai Pemahaman Kognitif Matematika konsep logika

\begin{tabular}{cc}
\hline Kategori & Jumlah \\
\hline Nilai Tertinggi & 100 \\
\hline Nilai Terendah & 22 \\
\hline Rata-rata & 59,42 \\
\hline$\geq$ KKM & 92 \\
\hline$<$ KKM & 152 \\
\hline
\end{tabular}

Tabel 3. nilai pemahaman kognitif matematika konsep logika dijelaskan bahwa perbedaan rentang perolehan nilai dari yang tinggi dan rendah terlalu jauh perbedaannya. Ada mahasiswa yang sangat tinggi sekali dan mahasiswa yang rendah sekali. Nilai tertinggi 100 dan nilai terendah 22, hal ini menjelaskan bahwa mahasiswa di pgsd memiliki karakter kemampuan yang beragam. Hal ini mempengaruhi rata-rata kelas yang berada ditengah dengan rata-rata 59,42.

Hal ini sangat bertentangan dengan hasil angket evaluasi pelaksanaan pembelajaran. Salah satunya adalah enyatakan bahwa siswa senang dalam mengikuti perkuliahan konsep logika. Hasil menujukkan bahwa mahasiswa senang mengikuti perkuliahan matematika. Hal ini dapat dilihat dari tabel berikut ini. Dimana 


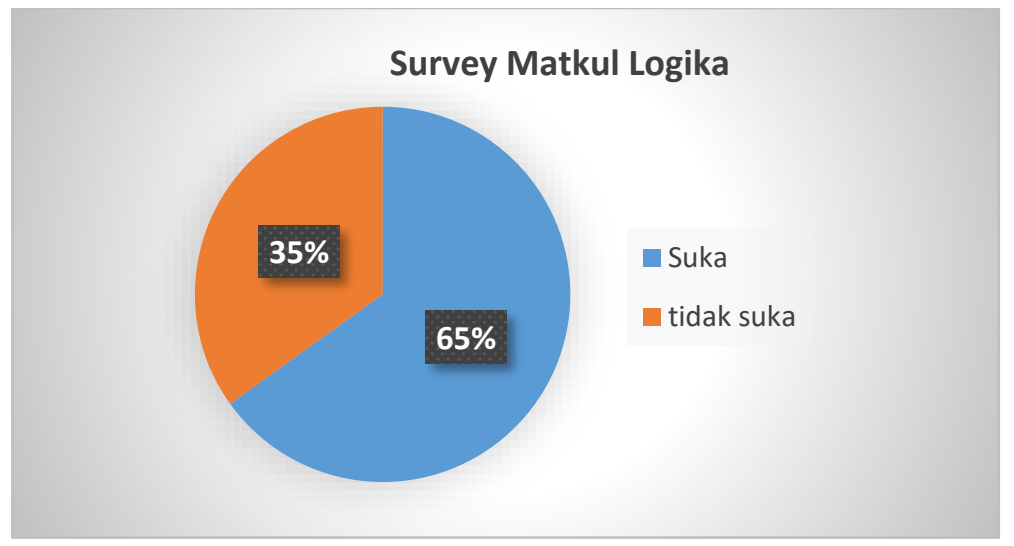

Gambar 3. Diagram data survey matkul logika

Tabel gambar 3 dijelaskan bahwa 65\% mahasiswa sening dan 35\% mahssiswa tidak suka karena mengalami kesulitam dalam memahami logika. Hal ini menunjukkan kesukaan mahasiswa pada pembelajaran matematika konsep logika. Mahasiswa suka mengikuti pembelajaran konsep logika, artinya mahasiswa juga sudah setuju dengan model yang digunakan oleh dosen.

Tidak hanya itu saja tetapi pertanyaan lebih lanjut bahwa pelaksanaan pebelajaran yang dilakukan oleh dosen mendapat reson yang baik oleh mahasiswa meskipun dari segi kognitif banyak mahasiswa yang belum tuntas. Hal ini menunjukkan hahwa mahaiswa senang mengikugti perkuliahan logika tetapi mahasiswa tidak memahami konsep logika yang dibicarakan.

Mahasiswa tertarik dengan perkuliahan tetapi mahasiswa tidak memahami konsep dari logika. Kesenangan mahasiswa dalam perkuliahan logika karena mahasiswa tertarik dengan model tugas dan juga video-video yang digunakan. Asumsi yang lainnya adalah mahasiswa menjawab senang karena takut jika menjawab tidak senang akan mempengaruhi nilai mahasiswa. Maka itu bisa menjadi asumsi alasan mahasiswa memilih suka bisa karena kawatir akan mempengaruhi penilaian oleh dosen.

\section{Kesulitan mahasiswa}

Kesulitan mahasiswa dalam penelitian ini dibagi menjadi dua yaitu kesulitan yang berkaitan dengan konsep dan kesulitan teknis dalam pelaksanaan daring. Pertama, Kesulitan berkaitan dengan konsep yaitu hasil tes yang rendah belum memenuhi KKM juga didukung dari data angket dalam google form yang menjelaskan bahwa 50\% mahasiswa sama sekali belum pernah mendapatkan konsep logika matematika. Hal ini peneliti tanyakan dalam virtual meeting karena latar belakang mahasiswa yang bukan dari SMA tetapi SMK. Mahasiswa menjelaskan bahwa ini menjadi pengalaman pertama memahami logika matematika. Selain itu juga mahasiswa yang dari jurusan non mipa ketika di SMA tidak mempelajari konsep logika matematika karena jurusan yang dipilih bukan jurusan mipa/Hal ini dapat dipahami karena latar belakang pendidikan mahasiswa calon guru SD memang berasal dari berbagai bidang pendidikan. Kesulitan yang dialami oleh mahasiswa adalah pada beberapa konsep, misalnya pada saat penentuan dari amcam-macam tautology seperti modus ponen,modus tolen, modus tolendo ponen dan silogisme. Kesulitan yang dialami mahasiswa lebih pada kesulitan dalam memahami konsep pada logika.

Kesulitan kedua yaitu berkaitan dengan teknis pelaksanaan pembelajaran daring bahwa kendala diluar konsep adalah kendala jaringan atau sinyal mahasiswa dalam mengikuti perkuliahan. Mahasiswa PGSD berasal dari beragam daerah mulai dari ujung barat samapai ke timur Indonesia. Biasanya mahasiswa kesulitan dalam melakukan presensi dan mengikuti perkuliahan. Hal ini tampak dari keterlambatan mahasiswa melakukan presensi kehadiran. Tidak hanya itu saja, mahasiswa mengalami keterlambatan dalam mengikuti zoom meeting dan setelah bisa bergabung dalam zoom meeting, mahasiswa mengalami kendala sinyal yang putus-putus. Kendala yang kedua adalah, ketika sinyal sudah membaik tetapi listrik padam dan menyebabkan semua aktivitas terhenti. Untuk beberapa tempat di sebelah timur Indonesia memiliki jadwal pemadaman lampu disetiap harinya. Sehingga untuk dapat mengikuti perkuliahan mahasiswa harus mencari tempat yang memiliki jaringan yang baik, maka terkadang solusi yang dilakukan oleh mahasiswa adalah ke kota kabupaten dan itu membutuhkan perjalanan waktu yang lama. 


\section{SIMPULAN DAN SARAN}

\section{Kesimpulan}

1. Pelaksanaan pembelajaran daring konsep logika sudah menggunakan aplikasi yang mendukung seperti whatsapp, LMS, Zoom, google meet, google form. Hal ini dapat dilihat dari total responden yang mengikuti

2. Analisis kemampuan kognitif mahasiswa diukur dengan tes yang sudah memenuhi standard dimensi kognitif menurut Taksonomi Bloom dan hasil ketuntasan mahasiswa mencapai 38\%, sedangkan jumlah mahasiswa dibawah KKM mencapai $62 \%$.

3. Kesulitan mahasiswa dapat dibagi atas dua macam yaitu kesulitan konsep dan kesulitan teknis pelaksanaan pembelajaran daring

\section{Saran}

1. Dengan adanya penelitian ini dapat diketahui pemanfaatan teknologi dalam proses pembelajaran dapat diterima oleh peserta didik, sehingga kedepannya perlu lebih ditingkatkan pemanfaatan teknologi informasi dalam pembelajaran.

2. Sistem yang telah dikembangkan memiliki kekurangan, maka peneliti memberikan beberapa saran yang dapat dijadikan bahan pertimbangan untuk pengembangan pembelajaran logika selanjutnya yang lebih inovatif

\section{UCAPAN TERIMAKASIH}

Berisi apresiasi pada berbagai fihak yang langsung terkait dengan penelitian beserta sumbangannya; Jika penelitian didanai oleh penyandang dana, sebutkan pula nomor SK atau kontraknya.

\section{DAFTAR PUSTAKA}

Darmawan, I. P. A., \& Sujoko, E. (2013). Revisi taksonomi pembelajaran benyamin s. bloom. Satya Widya, 29(1), 30-39.

Fatmawati, S. (2013). Perumusan Tujuan Pembelajaran Dan Soal Kognitif Berorientasi Pada Revisi Taksonomi Bloom Dalam Pembelajaran Fisika. Edu Sains: Jurnal Pendidikan Sains dan Matematika, 1(2).

Yusmin, E. (2017). Kesulitan belajar siswa pada pelajaran matematika (rangkuman dengan Pendekatan Meta_Ethnography). Jurnal Visi Ilmu Pendidikan, 9(1).

Hidayat, H., Hartono, H., \& Sukiman, S. (2017). Pengembangan Learning Management System (LMS) untuk Bahasa Pemrograman PHP. Jurnal Ilmiah Core IT: Community Research Information Technology, 5(1).

Kementrian pendidikan dan kebudayaan. Surat edaran no 4. Tahun 2020. Tentang pelaksanaan kebijakan pendidikan dalam masa darurat penyebaran corona virus disease (covid-19)

Kementrian pendidikan dan kebudayaan. Surat edaran sekretaris jendral no. 15 tahun 2020 tentang pedoman pei.iyelenggaraan belajar dari rumah dalam masa darurat penyebaran corona yirus $\mathrm{d} /$ sease (covid-19)

Kusuma, J. W., \& Caesarani, S. (2019). Penerapan Pendekatan Konflik Kognitif Terhadap Pemahaman Konsep Matematis Siswa Di Smp Negeri 7 Kota Serang. JIPMat, 4(1).

Kumalasari, A., \& Sugiman, S. (2015). Analisis Kesulitan Belajar Mahasiswa Pada Mata Kuliah Kapita Selekta Matematika Sekolah Menengah. Jurnal Riset Pendidikan Matematika, 2(1), 16-27.

Maulana. (2017) onsep Dasar Matematika dan Pengembangan Kemampuan Berfikir Kritis-Kreatif. UP Sumedang Press Gunawan, I., \& Palupi, A. R. (2016). Taksonomi Bloom-revisi ranah kognitif: kerangka landasan untuk pembelajaran, pengajaran, dan penilaian. Premiere educandum: jurnal pendidikan dasar dan pembelajaran, 2(02). 
Mawardi. (2020). Keefektifan Flexible Learning dalam Menumbuhkan Self-Regulated Learning dan Hasil Belajar Mahasiswa PGSD. Scholaria: Jurnal Pendidikan Dan Kebudayaan, 10(3), 251262.

Nuraeni, D., Uswatun, D. A., \& Nurasiah, I. (2020). Analisis Pemahaman Kognitif Matematika Materi Sudut Menggunakan Video Pembelajaran Matematika Sistem Daring di Kelas IV B SDN Pintukisi. Pendas: Jurnal Ilmiah Pendidikan Dasar, 5(1), 61-75.

Putria, H., Maula, L. H., \& Uswatun, D. A. (2020). Analisis Proses Pembelajaran dalam Jaringan (DARING) Masa Pandemi Covid-19 Pada Guru Sekolah Dasar. Jurnal Basicedu, 4(4), 861870.

Rahajeng, S. P. (2012). Kesulitan Belajar Matematika. Krida Rakyat, 2(2).

Santika, I. W. E. (2020). Pendidikan Karakter pada Pembelajaran Daring. Indonesian Values and Character Education Journal, 3(1).

Setyowati, N., \& Mawardi, M. (2018). Sinergi Project Based Learning dan Pembelajaran Bermakna untuk Meningkatkan Hasil Belajar Matematika. Scholaria: Jurnal Pendidikan Dan Kebudayaan, 8(3), 253-263.

Tias, A. A. W., \& Wutsqa, D. U. (2015). Analisis kesulitan siswa SMA dalam pemecahan masalah matematika kelas XII IPA di Kota Yogyakarta. Jurnal Riset Pendidikan Matematika, 2(1), 2839.

Kemendikbud. (2020). Permendikbud Nomer 3 Tahun 2020 tentang Standar Nasional Pendidikan Tinggi. Jakarta: Kemendikbud.

Iskandar, D., \& Senam, S. (2015). Studi kemampuan guru kimia sma lulusan UNY dalam mengembangkan soal UAS berbasis HOTS. Jurnal Inovasi Pendidikan IPA, 1(1), 65-72.

Wulan, A. R. (2008). Taksonomi Bloom-Revisi. Tersedia: http://www.google.com/url. 